\title{
एwev Ptosis in myasthenia gravis: Extended fatigue and recovery bedside test
}

\author{
Klaus V. Toyka, MD, FRCP, FAAN
}

Fluctuating double vision and ptosis are the hallmarks of extraocular muscle weakness in myasthenia gravis (MG). On sustained upward gaze, ptosis usually increases temporarily. The first description of using this fatigue sign has been attributed to the Scottish neurologist John Simpson. Cogan added his lidtwitch sign to the diagnostic bedside armamentarium. ${ }^{1}$ For many years, we have applied a fatiguerecovery test at the bedside, whereby the strength of the previously fatigued levator palpebrae muscle is improved shortly after voluntary maximal contraction of the antagonistic orbicularis oculi muscles, leading to a temporary improvement of lid opening. This extended fatigue maneuver provides an additional hint to the typical myasthenic weakness, in particular in the absence of double vision. Furthermore, we often observed that Cogan's lid-twitch sign may only be elicited when provoking recovery. This shortlived lid twitch is supposed to reflect the temporary recovery of phasic more than tonic motor units in the levator palpebrae muscles. Recovery of ptosis after 3 minutes of lid closure has been mentioned earlier by the late

Additional material related to this article can be found on the Neurology Web site. Go to www.neurology.org and scroll down the Table of Contents for the October 24 issue to find the title link for this article.
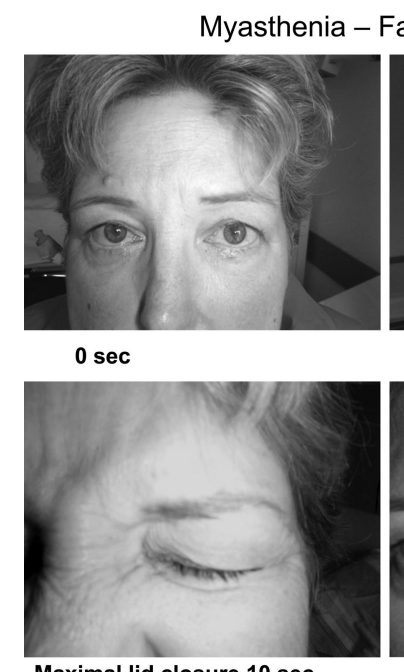

Maximal lid closure $10 \mathrm{sec}$

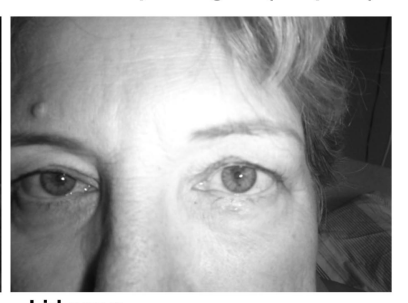

Lid open

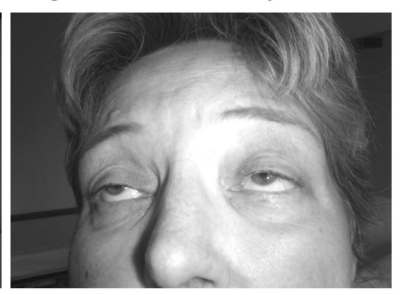

+10 sec upward gaze (Simpson)

Figure. (A) A 61-year-old woman with marked generalized myasthenia gravis, 2 days after plasma exchange treatment, with only minimal spontaneous ptosis at baseline. (B) After 10 seconds of upward gaze. (C) After 30 seconds of upward gaze. (D) Maximal voluntary lid closure for 10 seconds. (E) Almost complete recovery upon lid opening. (F) Reoccurrence of ptosis after another 10 seconds of upward gaze. Note that the patient has no heterotropia and did not report double vision at time of testing.

Dutch neurologist Hans Oosterhuis. ${ }^{2}$ However, the recovery test presented here requires only 10 to 30 seconds of maximal voluntary eye closure. In the differential diagnosis of pure ocular MG, the test proves particularly helpful in differentiating $\mathrm{MG}$ from other common disorders causing ptosis, e.g., Horner syndrome without miosis, mild forms of progressive external ophthalmoplegia, or habitual ptosis of the elderly where fatigue on upward gaze and re- covery after lid closure is less pronounced or absent (figure).

\section{Acknowledgment}

The author thanks Reinhard Hohlfeld, MD, Ralf Gold, MD, and Heinz Wiendl, $\mathrm{MD}$, for helpful suggestions.

\section{References}

1. Cogan DG. Myasthenia gravis: a review of the disease and a description of lid twitch as a characteristic sign. Arch Ophthalmol 1965; $74: 217-221$

2. Oosterhuis H. Clinical aspects. In: Myasthenia gravis. DeBaets M, Oosterhuis $\mathrm{H}$, eds. Boca Raton: CRC Press, 1993:19.

See also pages 1333, 1521-1523, 1525

Disclosure: The authors report no conflicts of interest.

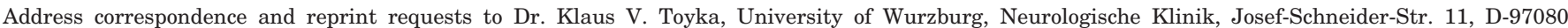
Würzburg, Germany; e-mail: kv.toyka@mail.uni-wuerzburg.de

1524 Copyright (C) 2006 by AAN Enterprises, Inc 


\section{Neurology}

\section{Ptosis in myasthenia gravis: Extended fatigue and recovery bedside test \\ Klaus V. Toyka \\ Neurology 2006;67;1524 \\ DOI 10.1212/01.wnl.0000240069.24338.c8}

\section{This information is current as of October 23, 2006}

\section{Updated Information \&} Services

\section{Supplementary Material}

\section{References}

Citations

Permissions \& Licensing

Reprints including high resolution figures, can be found at: http://n.neurology.org/content/67/8/1524.full

Supplementary material can be found at: http://n.neurology.org/content/suppl/2006/10/22/67.8.1524.DC1

This article cites 1 articles, 0 of which you can access for free at: http://n.neurology.org/content/67/8/1524.full\#ref-list-1

This article has been cited by 1 HighWire-hosted articles: http://n.neurology.org/content/67/8/1524.full\#\#otherarticles

Information about reproducing this article in parts (figures,tables) or in its entirety can be found online at:

http://www.neurology.org/about/about_the_journal\#permissions

Information about ordering reprints can be found online:

http://n.neurology.org/subscribers/advertise

Neurology $®$ is the official journal of the American Academy of Neurology. Published continuously since 1951, it is now a weekly with 48 issues per year. Copyright . All rights reserved. Print ISSN: 0028-3878. Online ISSN: 1526-632X.

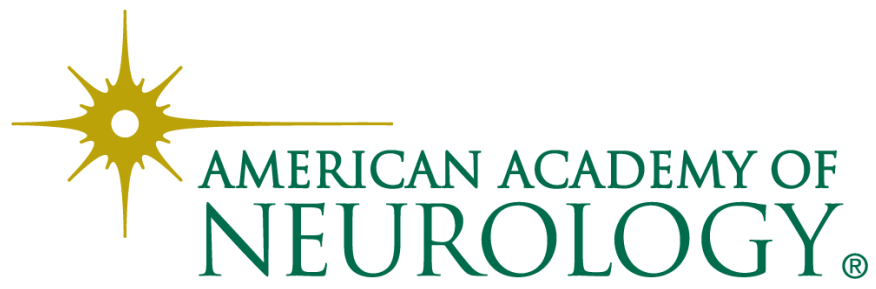

